\title{
Women's Perception of Partner Violence in a Ru- ral Igbo Community
}

\author{
Amobi Linus Ilika
}

\begin{abstract}
Partner violence is a serious public health problem affecting mostly women. This qualitative study assessed the perceptions of rural Igbo women of Nigeria of intimate partner violence. Information was elicited using in-depth interviews and focus group discussion. Women of childbearing age were selected from the various women age grades in Ozubulu, Anambra State, Nigeria. Findings revealed that the women generally condone and are complacent with intimate partner violence, perceiving it as cultural and religious norms. The women felt that reprimands, beating and forced sex affecting their physical, mental and reproductive wellbeing are normal in marriage. They did not support reporting such cases to the police or divorcing the man, they would rather prefer reporting to family members. They felt that exiting the marriage would not gain the support of family members. They also expressed fear for the uncertainty in re-marrying, means of livelihood after re-marriage, social stigmatisation, and concern for their children. Socio-cultural norms and structures favour partner violence in Anambra State of Nigeria. There is a need for advocacy and concerted action that will involve the educational, health, civil and religious sectors of the society to evolve sustainable structures that will empower women and provide support to enable victims to react appropriately to violence. (Afr J Reprod Health 2005; 9[3]:77-88)
\end{abstract}

\section{RÉSUMÉ}

La perception qu'ont les femmes de la violence du partenaire dans une communauté rurale Igbo La violence du partenaire est un gros problème de la santé publique qui affecte surtout les femmes. Cette étude qualificative a évalué les perceptions qu'ont les femmes rurales igbos du Nigéria de la violence chez le partenaire intime. Nous avons recueilli des données à l'aide des interviews en profondeur et des discussions à groupe cible. Les femmes en âge d'avoir des enfants ont été selectionnées à partir des différents groupes d'âge à Ozubulu dans l'état d'Anambra au Nigéria. Les résultats ont montré que les femmes en général ferment les yeux à la violence du partenaire intime,en la voyant comme des normes religieuses et culturelles. Les femmes ont estimé que les réprimandes, les raclées et les rapports sexuels forcés qui affectent leurs bien-être physique, mental et de reproduction arrivent normalement dans le mariage. Elles ne parlaient pas en faveur de signaler les cas à la police ou de divorcer d'avec l'homme. Elles préfèrent plutôt s'adresser aux members de famille. Elles estimaient que l'abandon du mariage n'attirerait pas l'appui des members de famille. Elles formulaient aussi une crainte à l'égard de l'incertitude d'un remariage, les moyens d'existence après le remariage, la stigmatization sociale et l'inquiétude au sujet de leurs enfants. Les normes et les structures socio-culturelles favorisent la violence du partenaire dans l'état d'Anambra du Nigéria. Il faut un plaidoyer et une action concertée qui impliqueront les secteurs éducatifs, médical, civil et religieux de la société pour élaborer des structures durables qui permettront aux femmes de s'assumer et d'assurer le soutien aux victimes de réagir comme il faut contre la violence. (Rev Afr Santé Reprod 2005; 9[3]:77-88)

Key Words: Perception, Partner, Violence, Women, Igbo

Correspondence: Dr Amobi Linus IIika, Community Medicine Department, Nnamdi Azikiwe University Teaching

Hospital, PMB 5025, Nnewi, Nigeria.Tel:08034743775; E-mail: linusilika@yahoo.com 
78 African Journal of Reproductive Health

\section{Introduction}

Discrimination and violence against women has been of great international concern and has received attention in many international conventions. In 1993 the UN General Assembly passed the Declaration on the Elimination of Violence against Women. It offered the first official definition of such violence against women as any act of gender-based violence, which results in or is likely to result in physical, sexual or psycho-logical harm or suffering to women including threats of such acts, coercion or arbitrary depriva-tion of liberty whether occurring in public or private life. ${ }^{1}$ The United Nations Convention on the Elimination of all forms of Discrimination Against Women (CEDAW) further described discrimination against women as any distinction, exclusion or restriction made on the basis of sex, which has the effect or purpose of impairing or nullifying the recognition, enjoyment or exercise of women, irrespective of their mental status on a basis of quality of men and women, of human rights, and fundamental freedom in political, economic, social, cultural, civil or any other field. ${ }^{2}$

The Beijing Declaration made at the Fourth World Conference on Women in Beijing, ${ }^{3}$ and the International Conference on Population and Development (ICPC) ${ }^{4}$ re-affirmed these conventions and commitments to eliminate gender-based discrimination and violence. The African Charter on Human and Peoples Rights specifically (in Article18) urged member-states to ensure elimination of every discrimination against women and the protection of the rights of women. ${ }^{5}$ Although Nigeria is a signatory to most of these treaties, violence against women continues to be pervasive among the Igbo ethnic group and in other parts of Nigeria. It has been reported by Odimegwu and Okemgbo among the Igbos in Ebonyi and Imo States of Nigeria ${ }^{6,7}$ and among the Yorubas in Western Nigeria by Odunjirin. $^{8}$

The Nigeria National Reproductive Health Policy lists gender-based violence as one of the key issues of reproductive health concern and has as one of its aims the limiting of all forms of gender violence. ${ }^{9}$ The policy document went further to state that the health-care system, in collaboration with other systems such as the legal, police, media, social and educational sectors and civil society organisations, has an important role to play in giving necessary support to victims and to give evidence when required. One of the proposed strategies in the policy document towards limiting or eliminating gender-based violence is the formulation and enforcement of legal instruments.

Intimate partner violence as a form of gender-based violence is known to be a prevalent public health problem in Nigeria ${ }^{6-8,10}$ and worldwide ${ }^{11,12}$ It occurs in various forms, such as physical assault like hitting, slapping, kicking and beating; and psychological abuse like constant belittling, intimidation, humiliation and coercive sex. ${ }^{13}$ It frequently includes controlling behaviours such as isolating a woman from family and friends, monitoring her movements, and restricting her access to resources. Intimate partner violence affects the reproductive, social, physical and psychological wellbeing of victims. ${ }^{11-13}$ There is a need for programmes and policies aimed at eliminating such violence to be on the priority list of public and reproductive health.

However, there are cultural and traditional differences in the perception of what constitutes intimate partner violence. What is considered as partner violence by international organisations or agencies or in Europe and America may not be perceived as violence in Africa. ${ }^{10,13}$ Similarly, societal response to partner violence will have cultural variations and perspectives. Perceptions of intimate partner violence by victims, perpetrators and the society will impact on policies and programmes designed to eliminate such violence. And since community attitudes, sociocultural norms and values largely shape perceptions and response to violence, they are critical issues to be understood and considered

African Journal of Reproductive Health Vol. 9 No.3 December 2005 
in strategy and programme planning to tackle such violence. For example, formulation of legislation on partner violence will require that legislators or lawmakers representing a constituency be convinced that partner violence is harmful and wrong. Co-operation and collaboration among civil societies will depend also on their perception of partner violence.

The attitude of victims of violence in particular is very crucial to the success of violence elimination programmes. Where the victim perceives partner violence as culturally acceptable, and a normal marriage experience built on male supremacy, she is most unlikely to report to appropriate health or law authorities, or respond appropriately to exiting the marriage. This qualitative study was conducted to ascertain women's perception of partner violence in a rural Igbo community in Nigeria. The implications for the reproductive health of women and elimination of gender-based violence are further discussed.

\section{Materials and Methods}

\section{Study Site}

The study was conducted in Ozubulu, headquarters of Ekwusigo Local Government in Anambra State of Nigeria between January and March 2004. Ozubulu is a rural community in the heart of Igboland in South-East Nigeria. The town has an estimated population of $35,000,{ }^{14}$ made up mostly of Christians. The major occupation of the inhabitants is farming. The unit of social organisation is the family, which is patrilineal and patriarchal. Groups of families who claim same ancestral descent or origin form a kindred (or umunna). Many kindreds form the ogbe (or village). Gender roles are culturally welldefined, with specific gender-based initiation and maturation rites.

The man is the head of the family and its breadwinner, while the woman is the procreator and housekeeper. Community government in the area is a mixture of gerontocracy and autocracy, though in serious cultural and religious issues, the opinion of the elder supersedes. Marriage is expected to be kept permanent, as long as the marriage is blessed with children. Marriage rites are elaborate and include paying of the bride price by the man and presenting stipulated gifts of drinks, yams, goats and cooked food to the kindred and community.

The woman signifies acceptance and subjugation to the man by receiving a cup of palm wine from the father, taking a sip while kneeling before the man and then giving back the cup of drink to him to finish up. The elders and community members will then applaud her and then settle to feast. These symbolic rites of marriage are very relevant to understanding and locating partner violence in Ozubulu. Marriage is therefore not a personal affair of the couple but a communal issue, a situation that culturally empowers family members and kindreds to intervene in husband-wife crises.

Ozubulu community runs an age-grade system, whereby individuals born within a decade are grouped into the same age grade. In the case of women, grouping is done based on the time the woman got married into the community, often signified by the traditional ima ogodo (clothing of wife) or ibupu mmaya (making the marriage public in the market), which is characterised by presentation of drinks and kolanuts to women in the town market. The different age grades hold their meetings, organise traditional dances and operate almost as fraternities. Seven women age grades exist, but only five fall within the reproductive age of $15-50$ years. The identified age grades were grouped as follows:
Otu Umuagbogho
$15-24$ years
Otu Ifunanya
25-30 years
Otu Osodi eli aku
$31-35$ years
Otu Osilike
$36-40$ years
Otu Oji-nwayo
$41-50$ years 
80

The age grouping was, however, not rigid, as some women who were older than 24 years were found grouped in the 15-24 years age grade because they were married into the village recently at an older age.

Local tradition and culture typical of the Igbo of south-east Nigeria dominates marriage and reproductive practices in the study community. Marriage pattern in the area is mostly monogamous, with few polygamous marriages. There are other peculiar marriage practices such as wife inheritance (ibachi nwanyi), whereby a daughter is kept unmarried in the paternal home to bear children and a widow does not re-marry but continues to 'bear' children for her dead husband.

\section{Methods}

Due to the sensitive nature of intimate partner violence issues, community-based household surveys are likely to pose a risk of aggravating further violence against female respondents or attack on the investigator from a suspicious violent partner. This in turn may affect the reliability of information obtained, as the women may feel reluctant to discuss freely. ${ }^{15}$ To circumvent this, however, the women age grades were used. Information for the study were collected at the age grade meeting places and days simultaneously with an ongoing study on widowhood practices by the author, in collaboration with Christian Women Organisation (CWO), in the area.

Five women age grades were identified, which fell within the age of 15-50 years. These age grades were chosen because they consisted of women of reproductive age, who were the most affected victims of intimate partner violence.

Ten focus group discussions and 25 in-depth interviews were held with women selected from the groups to represent women leaders, victims of partner violence and levels of education. Two focus group discussions and five in-depth interviews were held for each age grade. Each focus group comprised 8-10 persons and lasted
45 minutes to one hour, while the IDIs lasted about 40 minutes.

Leaders and officers of the age grades were recruited for the IDI, while other members were recruited for the FGD. This was done to forestall domination of the FGDs by the officers and leaders and to get more in-depth views and perceptions of the leaders. Interestingly, some women who were victims of partner violence were eager to be interviewed, as they saw it as an opportunity to draw attention to the practice, share experiences and institute action.

\section{Study Instrument}

An interview guide was prepared by the researcher to cover the thematic areas, which include presence of violence, type of violence, reaction to violence, effect on victim and reporting of violence. To ensure validity and reliability of data, eight medical and social science undergraduates were recruited and trained on the conduct of the interview and the art and logistics of the field work. The field guide was pre-tested with student interviewers among women of similar women age-grades in a different village. The purpose and nature of the study were explained to participants and their consent obtained prior to interview. The interview was conducted in the local language. The in-depth interviews and focus group discussions were tape-recorded as well as written, which were later transcribed and analysed.

\section{Results}

There was unanimous agreement among the women that intimate partner violence was pervasive in the community, which had affected their physical, mental and reproductive health. Most of the women in both the FGDs and IDIs agreed that their first ten years of marriage were characterised by fights, bullying and intimidation. They ascribed the pervasiveness to the man's wanting to assert authority and ownership right

African Journal of Reproductive Health Vol. 9 No.3 December 2005 
from the beginning.

There is virtually no family where the husband never beat or scolded his wife. In fact, within the first years of marriage, it is fighting and wrestling.

(FGD, 36-40 years)

The women experienced verbal, physical and psychological violence exhibited in scolding and abuses, beating, forced and non-consensual sex, and sending the woman out of the marriage home to her parents.

He beat me mercilessly and all my face was bruised and battered. I could not go to the market for four days. In addition to the pain and discomfort, I could not stand the anguish and shame of responding to inquisitive neighbours. (In-depth interview with a 26-year old mother of three)

Most of us have more than the number of pregnancies we would ordinary want to have. The men will force you (to have sex) and you dare not refuse. He will remind you that you are not a girlfriend, and that he paid bride price on you. After all, they do not know the pains of pregnancy and labour. (FGD, 31-35 years)

Certainly, most of the men will bark and scold you to the point of losing your self-esteem. They will assert their superiority and threaten you with either sending you bome to your parents or marrying a second wife. Men are overbearing generally. (FGD, 15-21 years)

He sent me home to the village because I confronted his girlfriends. By the time I spent one month at home, I had no money to meet my daily needs with my nine-month old baby. Everybody I complained to said I was foolish to have confronted him as long as he provided enough money and food for me and my children. I started feeling guilty and ashamed. (In-depth interview with a 22-year-old mother with her first child)

Although most of the women admitted that violence affected their health and wellbeing, they generally perceived that a husband has the right to control his wife, and that the wife is obliged to obey the husband in every situation. They believed that it is the tradition and a culturally accepted pattern.

\section{A busband has the right to scold her wife if she does something wrong. As the head of the family who paid dowry price on her head, he has the right to reprimand or scold her. A good wife should not exchange words with the husband. It is a mark of disobedience or challenge to bis manhood. (FGD, 41-45 years)}

The Igbo word for such exchange of words is ntu nsalu (talking back), which justifies verbal abuse by the man.

Some of the women perceived wife- beating as a corrective measure, or a chastisement. They, however, said the beating should not be severe and should not be done very often. Slaps, kicks and blows were considered to be too severe, while giving a number of strokes on the palm of the hand was considered to be acceptable. In the group discussions, participants agreed that:

A busband can beat the wife if she does something wrong. It is a corrective and training measure. The man however should realise that women are weak and, therefore, beat her mildly or moderately. (FGD, 41-51 years)

A woman deserved beating if she talked back on her husband, disobeyed the husband, refused him sex, presented a poorly cooked food, or late meal and failed to care for the children. She could also be beaten if she abused or disrespected her husband's parents or relations and challenged the busband openly if she saw bim with another 
82 African Journal of Reproductive Health woman. This should be rare, and not on slight provocation, after all if he hits the wife hard and injures her be will incur hospital bills. (FGD, 41-51 years)

On sexual coercion, the women were of the view that it is a "hide and seek" game.

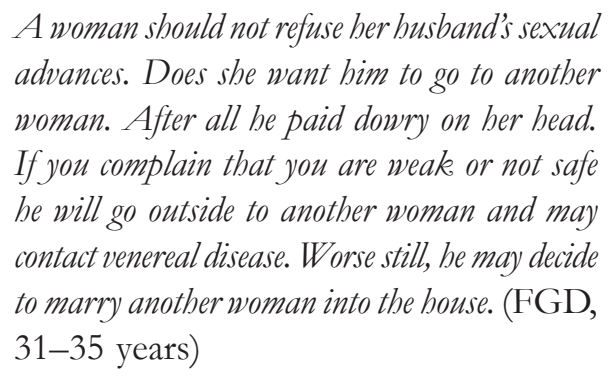

The women did not agree that there could be rape within marriage. A woman with her fifth child and six months into another pregnancy exasperatingly responded:

There is nothing like rape within marriage. It is hide and seek game. Sometimes you overcome him. Other times he has the upper hand. Next morning he pays back with enhanced feeding money and gifts to appease you. If you tell people your husband raped you, they will raise eyebrow and utter cynically, "who else should rape you". Then you will look stupid and ashamed.

The women's perception on restricting a wife's movement was incoherent. They felt that limiting the woman's movement and interaction with other people is a protective mechanism to prevent her from running into trouble, and sometimes it is a mark of affection by her husband. They described it as ibe akwa nwayi (being possessive). However, most women in the lower age-grades (15-24 years) felt that a woman should be given more freedom, especially now that women work and contribute to the family upkeep.
The man's control should be within a reasonable limit. Men were all in all when women were mostly housewives and were not contributing to the family income. Now that some women read, work and trade and, therefore, earn and contribute to the family income, the situation should be different. (FGD, 15-24 years)

Naturally a husband should control the wife's movement and actions. It is for her own good. The man is the head and protector of the family and knows the traps, which the woman may not appreciate. This should, however, be foryoung wives who have not yet mastered the cultural terrain and tricks to navigate through social life. (In-depth interview with a 45-yearold woman leader)

Who does not know that the man is lord of the house? After all who lies on top when they are making the child, the man or the woman? $\mathrm{Na}$ ture made it that the man is always on top and dictates the pace or tune. The problem is that some of the men, however, overdo it as if you are a slave. (FGD, 15-24 years)

The women, however, felt that it causes a lot of psychological distress for a man to send his wife to the village or her father's house as a punitive measure, as it is humiliating and stigmatising.

It is not good to punish or humiliate a wife by sending her to the village. That will stigmatise her as a bad mannered woman and make her lose her self-esteem. It is even better to flog her quietly in the room. (In-depth interview with a 38-year old woman)

A woman observed strongly:

I work and earn a good salary and even pay a good part of the children's school fees. In some

African Journal of Reproductive Health Vol. 9 No.3 December 2005 
families now women are even the breadwinners. Men should therefore not control the wife's movement and actions unduly. It was feasible in the olden days when every wife was a bousewife. Now, women work and earn and contribute to the family income. They should be freer. (In-depth interview with a 32-year-old civil servant)

The women's opinion on confronting a husband when he goes after another woman showed a situation of both fury and helplessness. While some of the women felt that it was wrong to challenge him openly as long as he provides for the wife and family, others felt that he should be challenged. Some of the women also perceived that challenging him might worsen the situation and threaten the stability of the marriage.

Men are not satisfied with one woman. If he must keep another woman, he should do it secretly. If he brings her to the home I will fight back. That is a disgrace to me. (A 28-yearold wife and university graduate)

As long as he provides food, money and pays the school fees, you only beg him to stop or complain to his brothers because be may contact venereal disease and spread it to you. (A 26-year-old housewife)

If you challenge him, he may decide to marry the woman as a second wife or, worse still, keep late nights. Men hate challenge because of their ego. (FGD, 25-30 years)

Most of the women in all the focus group discussions felt that the proper people to report to if a husband is involved in extra-marital affairs are family members, husband's friends, pastors and other religious leaders. Victims can report to health care providers only if they have serious injuries that warrant seeing a health care-giver. They did not considered it right to report to the police.

It is not good to report your husband to the police. If you drag him to the police or court, do you think be will agree to marry you again. That will scatter the family. The whole family and village will be against the woman. They will say she is 'too civilised' (o walu anya). Her eyes are too much. Besides, what can the police do, except to extort money from him? That money can be saved for family use still. (A 30year-old mother in FGD)

The best people to report to are your husband's friends or family, or the church pastor. When they advise the man he may listen. When the beating becomes too much you run home to your parents, and when he comes with palm wine to take you back as required by tradition, your parents will reconcile both of you.

A 24-year old mother of two observed that it is sometimes good to match violence with violence, especially when the man refuses to listen to advice and persists to beat his wife. She narrated her encounter with her husband:

He beat me mercilessly for the third time and I reported to my brothers. My brothers raided our house one morning and beat him thoroughly in retaliation. I was so frightened and touched that I started to plead on his behalf to prevent further beating. When my brothers left, I thought he would avenge or send me home, but he held me to his chest, apologised for having beaten me and confessed that he never knew I loved him so much as to plead for or to defend him. Since then he has never beaten me. If your husband beats you, you should report him to your big brothers.

\section{Exiting Marriage}


84 African Journal of Reproductive Health

The in-depth interviews and focus group discussions also revealed difficulties in exiting the marriage. Such difficulties follow considerations of children's welfare because they might be left in the custody of their father according to Igbo tradition. The rare possibilities of re-marriage, non-acceptance of the man at her father's family home, repayment of bride price, means of subsistence, loss of self-esteem and the stigma of being a failure in marriage are major demotivators.

It is not easy to exit the marriage when you have children. Who will you live the children behind for? If they die because of lack of care, the man has chances of getting children from another woman, but the woman's reproductive time is limited. Besides, when the children grow, if they survive, their father will tell them you abandoned them when they were young and, naturally, they will hate you and refuse to care for you in your old age. (FGD, 31-35 years)

One of the women leaders in the in-depth interviews observed:

If you stay in your father's home, very soon you start quarrelling with your brother's wife who may see you as a burden and an intruder. If you go to town or hire a place to live and do some business to earn a living, they will gossip that you have gone into prostitution. Di bu ugwu (the husband is the woman's pride), even if he beats you everyday. The family will not support you because they will be expected to pay back the dowry price and other marriage costs which your husband incurred. This is quite difficult. Besides, they have to accommodate you and provide food for you and your children. (FGD, 25-30 years and 31-35 years)

The women were of the view that remarrying is not easy, especially if one wedded in the Catholic Church. They said that the Church would stop the woman from receiving sacrament. Most of the women also said that the man would eventually change as he grows older. In addition, in the later days of life when the woman's children grow to adulthood, the woman becomes the lord, as she rallies the children's support and protection. This is a strong motivation to remain in even a violent marriage.

The woman's world is best in the evening of life (Uwa mgbede). The children will now be adults and support and protect her. In fact the woman now controls the house. When men are young, they tend to be obtrusive and domineering because they want to assert their manhood and authority, and show that they cannot be controlled by a woman. They hate to hear such comments as nwunye ya na anu ya (the wife is marrying him). But as the marriage grows older be changes. All a woman needs to do is to have patience; he will change.

\section{Discussion}

The study revealed general acceptance and complacency with intimate partner violence among the study women; an attitude that has been observed in other studies among the Igbo residing in the western parts of Nigeria. ${ }^{16}$ This is in spite of the fact that partner violence affected their health and wellbeing. This perception is rooted in the cultural, religious and societal norms that assign gender roles, rights and responsibilities. ${ }^{17-19}$ Ejiofor also describes it vividly in his anthropological study of the area:

The father is the accepted head of the family. He is conscious of it and he strongly lays down the general policy in all matters affecting the family. The mother is the heart of the home, the procreator and governess of the house. For all major needs, she gets the necessary funds from the father who controls the family economy. The man's first boast is the ability to run a family. He takes direct charge of his own family and does not accept dictation or brook interference. ${ }^{17}$

This perception of male dominance and 
female subordination to the man has been observed in many parts of Nigeria and other developing countries. ${ }^{13,17-19}$ The man's supremacy is further predicated in the payment of dowry, or bride price, a process that conveys and confirms the right of ownership and the duty of care and control over the wife and the children, as well as initiates the man to legitimate fatherhood or manhood (di bi uno). On the other hand, it subordinates the woman as something acquired. This is explicitly manifested and glamorised during the marriage ceremony in Igbo culture; when the young lady has to kneel in a symbolic gesture of submission while presenting a cup of palm wine to her husband. The women expressed the perception and consciousness of ownership by their husband repeatedly. The implication is that the abused woman feels obliged to obey, subscribe and succumb to her husband's desires at all times.

Furthermore, religious norms and teachings supporting female subjugation and subordination are well documented in the Holy Bible and other church documents. ${ }^{20,21}$ The Pauline discussion on marriage and the Code of Canon Law explicitly forbids divorce or exit from marriage. It also regards re-married divorced women as adulteresses who should be denied Christian church rites and privileges. The Bible story of the creation of a woman as a helper from the rib of a man and Paul's exhortation to "wives to be submissive to their husbands" summarise the Christian religious teaching. Umezurike has observed that the inequality is even more severe and more strictly observed in Islamic and the heathen religions. It seems therefore that the three major world religions maintain and practice inequality of men and women as a fundamental doctrine..$^{22}$

Odimegwu and others have also observed gender inequality and inequity among the Igbo of Imo State and Abakaliki in Nigeria. ${ }^{6,7}$ Uchem has extensively criticised this Christian religious perspective, and Aide has highlighted the implication of such religious perspectives for the reproductive right of women in the Moslem area of Egypt. ${ }^{18,23}$

It is important to observe that the process of gender socialisation and assignment of gender roles begin from birth in the study area. At the announcement of the birth of a male-child, the women sing folk-songs that invite a man who has a gun to fire it: onyi ji egbe gbaa nga, meaning: "He who has a gun, let him fire". In contrast, however, at the birth of a female baby a person with money is invited: Onye ji ego gbaa nga, meaning: "He who has money, let him come forth".

The response to the birth of the male-child pre-announces a person who has authority to live in the house and protect his family, while that of the girl-child invites rich suitors. The gender socialisation process goes from childhood through adolescence to adulthood and breeds women subjugation. Before adulthood, the gender stereotypes and gender-defined roles become the accepted way of life and standard. The female children help their mothers with domestic work while the male children relax with their fathers awaiting meals after the day's work, even if both the men and women went to work in the farm and came back together.

However, although the women were complacent and seemed to condone partner violence, they were conscious of the fact that after all, the woman owns the day. They described this as una mgbede (life in the evening time). "He who laughs last laughs best." This forms an important coping mechanism or motivation for not exiting marriage. This perception is anchored on two points. First, because the men are generally older than their wives in the study area, they are likely to age faster, become weaker and less obtrusive and domineering. At this stage they will change and succumb to the more active wife who now provides care. Second, children are most often aligned to their mothers when they grow to 
86 African Journal of Reproductive Health

adulthood. Among the Igbo, it is a common joke that adult sons and daughters usually present gifts of tobacco snuff and spirits to their fathers, while they offer cloth and money and holiday trips to their mothers. The adult children provide extra care for their mothers as well as protection against threats of violence from their fathers. This is a gender-orientated practice that favours women and serves as a motivation for the women to condone or be complacent with violence.

The attitude of not reporting to the police also follows the cultural norms and tradition that sanction reporting family issues to the law enforcement agents. Reporting one's husband to the police is viewed as an affront to the husband and disrespect to family members and elders whose extended family member roles include arbitrating in such matters. Besides, reporting to the police is construed as a punitive measure aimed at creating unnecessary conduit for wastage of the husband's funds, as police officers are perceived to be only interested in extorting money from the man rather than in prosecuting him. The woman is also at the risk of being stigmatised as being 'too civilised' (owalu anya), a derogatory remark that implicates her as a culture deviant, thereby putting her in double jeopardy of losing the existing marriage and having slim chances of remarrying.

The woman also finds it difficult to exit marriage because she needs the support of her family members, who are traditionally bound to refund the bride price if the marriage fails, to do so. Such support is very rare because it has serious financial implications on the woman's father. $\mathrm{He}$ must refund the bride price on his daughter and pay back other traditional marriage expenses. On the other hand, if a man sends his wife away he must wait until the woman gets another husband before he can ask for a refund of the dowry he paid. These traditional marriage processes discourage divorce and stabilise marriage. Unfortunately, however, it hinders abused women from exiting turbulent or violent relations. In addition, there is a cultural belief that a husband is the glory of a woman. An unmarried or divorced woman is regarded as a failure and a "free woman" who lacks esteem and male protection.

The reproductive health implications of these perspectives are obvious. A woman is at high risk for unwanted pregnancy, abortion and maternal depletion if she is denied the right to determine the timing and spacing of pregnancy and her desired family size, because she is culturally expected to be submissive. This will contribute to maternal morbidity and mortality. Although the women recognised and admitted that violence affects their reproductive and mental health, they could not respond appropriately to free themselves due to cultural constraints. This suggests the need for an enabling environment to help the women meet such challenge. Although no one who understands the power of culture and religion dare challenge this norm, we must understand that some cultural and religious norms have led to the neglect, and sometimes acceptance of violation of women's reproductive and human rights.

One of the Millennium Development Goals adopted unanimously by the United Nations in September 2000, which Nigeria is a signatory to, is to promote gender equality and empower women. One of the aims is to achieve equality in the ratio of girls to boys in schools. ${ }^{24}$ This needs to be pursued assiduously by governments. Unfortunately, some of the rights of women, as enshrined in CEDAW and other human rights documents, are not enforced and are not justiceable in Nigeria. ${ }^{22}$ Experience, however, has shown that female education, gainful employment of women and improved earning have radically changed some perspectives of Igbo culture in issues affecting women.

For example, in the last three decades parents and families greatly influenced the choice of partner and place of marriage for their daughters. They even forbade marriages outside their towns 
or neighbouring towns (nwanyi-mba). The situation has now changed totally with cross-country and inter-tribal marriages being accepted and tolerated by parents when their daughters make the choice. This has been made possible by urbanisation, migration, education and employment, which have to a great extent empowered women to make their choices without undue parental restrictions. This suggests that some cultural practices that deny women of their rights can be changed. It also underscores the need for female education as an entry point to preventing gender-based violence.

In conclusion, the study highlights deeprooted influence of culture and religion on the perspectives of partner violence among Igbo women in Anambra State of Nigeria. This calls for a multi-sectoral approach to creating public enlightenment and evolving structures that will empower women and provide an enabling environment to help victims react appropriately.

\section{REFERENCES}

1. United Nations General Assembly on the Elimination of violence against women. Proceedings of the 85th Plenary Meeting, December 20, 1993.

2. United Nations Convention on the Elimination of all forms of Discrimination against women (CEDAW) 1999.

3. United Nations Report of the Fourth World Conference on Women, Beijing, China, 415 September 1995.

4. United Nations Report of the International Conference on Population and Development, Cairo 5-15 September 1994.

5. African Charter on Human and Peoples Rights, 1986.

6. Odimegwu $\mathrm{CO}$ and $\mathrm{CN}$ Okemgbo. Women against women; women's perception of girl-child status in Abakaliki area of Nigeria. Inter J Soc Policy Stud 4(2): 73-84.
7. Okemgbo Chris N, Omideyi AK and Odimegwu CO. Prevalence, patterns and correlates of domestic violence in selected Igbo communities of Imo State, Nigeria. Afr J Reprod Health 2002; 6(2): 101-104.

8. Odujirin $\mathrm{O}$. Wife battering in Nigeria. Int $\mathrm{J}$ Gynaecol Obstet 1993; 41: 159-164.

9. FMOH. Nigeria National Reproductive Health Policy and Strategy, 2001.

10. Ilika AL, Okonkwo IP and Adogu P. Intimate partner violence among women of childbearing age in a primary health care centre in Nigeria. Afr J Reprod Health 2002; 6(3): 53-58.

11. Leuvng WC, Leung TW, Lam YY and Ho PC. The prevalence of domestic violence against pregnant women in a Chinese community. Int J Gynaeol Obstet 1999; 1: 23-30.

12. Fiktee FF and Bhah LI. Domestic violence and health of Pakistain women. Int J Gynaecol Obstet 1999; 65(2): 195-201.

13. Heise L, Elisberg M and Gotthermoeller M. Ending violence against women. Pop Reports 1999; Series 1 (11).

14. National Population Council, 2002.

15. Rachel Jewkes, Charlotte Watts, Naema Abrahams, Love-day Penn-kekens and Claudia Gracia-Moreno. Ethical and methodological issues in conducting research on gender-based violence in southern African. Reprod Health Matters 2000; 8(15): 93-103.

16. FMH/WHO. Gender-based violence. A survey of Lagos mainland metropolis. 1999.

17. Ejiofor Lambert. Dynamics of Igbo Democracy. Behavioral Analysis of Igbo Politics in Agiuyi Clan. Ibadan: University Press, 1981; 36-93.

18. Uchem Rose N. Overcoming Women's Subordination, an Igbo African and Christian Perspective. Enugu: Snapp Press, 2001; 18-72.

19. Okeke GC. Christian Marriage in Nigeria in the 21st century. Problems and challenges. Bigard Theol Stud 2002; 2: 19-35.

20. The Code of Canon Law. London: Collins Liturgical Publications, 2001.

21. The New American Bible. New York: Tho- 
88 African Journal of Reproductive Health

mas Nelson, 1970; Genesis 2: 21-22, Colossians 3: 18-19.

22. Umezurike IA. Convention on the elimination of all forms of discrimination against women (CEDAW). The possibility of its justiciability in Nigeria: In: Nweze CC and Nwankwo Oby (Eds.). Current Themes in the
Domestication of Human Rights Norms. Enugu: Fourth Dimension, 2003; 123-142.

23. Aide Seif El Dawla. Reproductive rights of Egyptian women. Issues for debate. Reprod Health Matters 2000; 8(16): 45-54.

24. World Bank. Measuring the World Development. World Bank Atlas. 35th Edition. Washington DC: World Bank, 2003; 14-15. 